\title{
GERAKAN PEMBARUAN PENDIDIKAN AL ITTIHADIYAH DI SUMATERA TIMUR, 1935-1975
}

\author{
Soiman \\ Universitas Islam Negeri Sumatera Utara Medan \\ J1. Willem Iskandar Pasar V Medan Estate, Sumatera Utara, 20371 \\ e-mail: soiman@uinsu.ac.id
}

\begin{abstract}
Al Ittihadiyah Education Modernisation Movement in East Sumatra, 1935-1975. This study examines the ideas of Al Ittihadiyah's education in the fields of education and education methods. This study was motivated by the scarcity of references about organizations from East Sumatra, especially Al Ittihadiyah's movements and ideas in the field of education. This study is the result of qualitative research. Data obtained from document study activities which was then analyzed by the method of content analysis and enriched using interview techniques. This study proposes findings that Al Ittihadiyah contributed to the development of Islamic education in North Sumatra, starting from the Colonial era to post-independence. As with other reforming Islamic organizations, Al Ittihadiyah prior to independence had carried out reforms in curriculum and educational methods, so that this organization played a role in improving the quality of education of Muslims in the archipelago. However, in the latest development, it appears that this organization has relatively little role to play in the development of Islamic education since educational institutions are no longer managed by organizations centrally.
\end{abstract}

Keywords: Al Ittihadiyah, education, East Sumatra, Malay 


\section{Pendahuluan}

Pada awal abad ke-20, beberapa organisasi keagamaan melakukan pembaruan dalam bidang pendidikan seperti Nahdlatul Ulama, ${ }^{1}$ Al-Jami'at Al Khairiyah, Al Irsyad, ${ }^{2}$ Persis, ${ }^{3}$ Muhammadiyah, ${ }^{4}$ dan Al Jam'iyatul Washliyah. ${ }^{5}$ Para peneliti telah meneliti peran organisasi Islam tersebut dalam bidang pendidikan. Akan tetapi, penelitian terhadap peran organisasi Islam di luar Jawa dalam bidang pendidikan cenderung terabaikan.

Di antara organisasi Islam yang terabaikan adalah Al Ittihadiyah. Buktinya, tidak banyak riset-riset ilmiah yang ditujukan pada organisasi yang lahir sebelum Indonesia merdeka ini. ${ }^{6}$ Studi ini akan mengkaji bagaimana gerakan pembaruan yang dilakukan Al Ittihadiyah dalam bidang pendidikan, terutama dalam aspek kurikulum dan metode pendidikan, di Sumatera Utara sejak tahun 1935 sampai 1975.

Studi ini merupakan penelitian studi kasus, yakni penelitian tentang status subjek penelitian yang berkenaan dengan suatu fase spesifik atau khas dari keseluruhan personalitas. Subjek dari jenis penelitian ini dapat berupa individu, kelompok, lembaga, maupun masyarakat. ${ }^{7}$ Dalam konteks ini, subjek studi ini adalah organisasi Al Ittihadiyah. Untuk menjawab fokus masalah, studi ini memanfaatkan studi dokumen, yaitu data diperoleh dari analisis isi terhadap dokumen organisasi terutama Anggaran Dasar dan Anggaran Rumah Tangga Al Ittihadiyah, hasil-hasil Muktamar Al Ittihadiyah serta dokumen-dokumen Al Ittihadiyah tentang kegiatan pendidikan Islam terutama tentang kurikulum dan metode pendidikan Islam. Untuk melengkapi data, akan digunakan teknik wawancara, dimana akan diwawancarai sejumlah tokoh yang memahami masalah kurikulum dan metode pendidikan Al Ittihadiyah. 


\section{Sekitar Sejarah Al Ittihadiyah}

Al Ittihadiyah didirikan di antara Perang Dunia I dan Perang Dunia II, tepatnya di zaman penjajahan Belanda. Al Ittihadiyah muncul dan lahir setelah penjajah Belanda semakin aktif melakukan adu domba, untuk memecah belah persatuan dan melemahkan kekuatan umat Islam. Perpecahan dalam segenap lapisan masyarakat semakin terjadi, terutama antara yang berlatar belakang pendidikan Islam dan pendidikan non Islam. Hal ini karena pengaruh politik pecah belah yang dilakukan penjajah Belanda.Jurang pemisah antara Kaum Tua dan Kaum Muda, kaum intelektual dan ulama demikian juga antara satu suku dan suku yang lain terus bertambah besar. ${ }^{8}$

Dalam bidang pendidikan agama, perguruan-perguruan Islam sebagai sumber kekuatan umat Islam belum begitu teratur dan berkembang menurut semestinya. Dalam keadaan demikian, untuk mempersatukan pemikiran dalam memperjuangkan tuntutan syariat Islam dan kemerdekaan Indonesia, tampillah Syekh Ahmad Dahlan (w.1938), seorang ulama asal Langkat, yang pada waktu itu baru kembali dari luar negeri setelah menyelesaikan pendidikannya di Universitas Al Azhar, Kairo, Mesir. Pada tanggal 21 Syawal 1354/27 Januari 1935 di Medan, Syekh Ahmad Dahlan bersama para ulama dan cerdik pandai serta murid-muridnya sebanyak 200 orang meresmikan pendirian organisasi Islam yang bernama Al Ittihadiyah. ${ }^{9}$

Pada sekitar masa berdirinya Al Ittihadiyah, kondisi sosial di Indonesia sedang memuncak pertentangan antara para ulama dan para cendikiawan hasil didikan Belanda. Para ulama menuduh kelompok cendikiawan menilai kaum ulama sebagai kelompok yang kolot dan bermartabat rendah. Sebagai jawaban atas adanya pertentangan tersebut, para ulama yang merasa prihatin bersatu mendirikan organisasi Al Ittihadiyah. Tujuan didirikannya adalah meninggikan agama Allah SWT., mempersatukan umat, dan 
meningkatkan persatuan bangsa. Sasaran kegiatannya adalah pengaturan, pembinaan dan pengembangan lembaga-lembaga pendidikan Islam, tempat ibadah, dan organisasi-organisasi sosial keagamaan. ${ }^{10}$ Untuk mencapai tujuan organisasi Al Ittihadiyah memiliki program kerja antara lain ialah membangun perguruanperguruan, madrasah-madrasah dan sekolah umum, mengatur kesempurnaan pelajaran, pendidikan dan kebudayaan. Untuk mencapai tujuannya Al Ittihadiyah juga menempuh usaha-usaha seperti mengelola lembaga pendidikan dari tingkat dasar hingga perguruan tinggi, mengembangkan misi Islam yang dinamis, menyelenggarakan pengasuhan anak-anak yatim, dan meningkatkan kesejahteraan masyarakat. ${ }^{11}$

Dalam bidang pendidikan, selain mengelola lembaga pendidikan agama dengan menggunakan kurikulum Departemen Agama, Al Ittihadiyah juga mengelola lembaga-lembaga pendidikan umum yang didasarkan pada kurikulum Departemen Pendidikan dan Kebudayaan. Sesuai dengan usaha Al Ittihadiyah untuk mewujudkan pembangunan manusia Indonesia seutuhnya, kurikulum yang digunakan pada lembaga-lembaga pendidikan Al Ittihadiyah diarahkan agar sesuai dengan tujuan pendidikan organisasi tersebut, yakni terwujudnya kesatuan antara pemberian ilmu pengetahuan, agama dan keterampilan. ${ }^{12}$

\section{Kurikulum di Lembaga Pendidikan Al Ittihadiyah}

Al Ittihadiyah sebagai organisasi keagamaan Islam memiliki dan mengelola lembaga pendidikan Islam, dan sejak awal telah berupaya untuk merumuskan atau menyusun satu kurikulum pendidikan Islam yang dapat dipakai di seluruh lembaga pendidikan Islam yang ada dalam naungannya. Ditambah lagi dengan semakin meluasnya perkembangan perguruan Al Ittihadiyah, baik yang didirikan dan diatur oleh Al Ittihadiyah sendiri, maupun yang dibangun oleh Al Ittihadul Wathaniyah Labuhan Batu dan Al 
Ma'shum di Deli Serdang, maka untuk keseragaman dari seluruh perguruan Al Ittihadiyah dan yang bergabung dengannya, serta untuk memudahkan bagi Al Ittihadiyah setiap tahun mengadakan ujian umumnya, dalam rapat bersama yang diadakan pada tahun 1957, antara P.B. Al Ittihadiyah bidang Pendidikan dan Pengajaran yang diwakili oleh H.M. Tarmizi, H. Mahmud Abu Bakar, M. Arsyad Rahman dan Iljas Amin dan dari Perguruan Al Ittihadul Wathaniyah Labuhan Batu diwakili oleh Bachroem Azhar, serta dari al Ma'shum diwakili oleh Ustaz Ghazali. Akhirnya setelah beberapa kali mengadakan pertemuan dan rapat bertempat di rumah Ustaz H. Mahmud Abu Bakar dan setelah mempelajari dan membahas tiga rencana pelajaran yang telah ada pada masingmasing perguruan, diambil perumusan Rencana Pelajaran dari seluruh Madrasah Al Ittihadiyah dan yang bergabung dengannya.

Adapun mengenai rencana pelajaran untuk sekolah-sekolah umum seperti SR, SMP, SMA, Pertama/Atas, dan SMK Al Ittihadiyah, berhubung karena sekolah tersebut diprogramkan untuk mengikuti ujian akhir nasional negeri, rencana pelajarannya disamakan dengan rencana pelajaran SR, SMP, dan SMA yang telah diatur oleh Kementerian P.P. \& K dengan ditambah pendidikan agama Islam pada setiap tingkatan dan kelasnya.

Menurut penjelasan bapak Syahbuddin KS yang pada masa awal pembinaan madrasah-madrasah Al Ittihadiyah ia mengasuh sebuah Madrasah Ibtidaiyah di jalan Angsana Medan, diperoleh keterangan bahwa sejak awal berdirinya Al Ittihadiyah pada tahun 1935, sudah ada beberapa madrasah tingkat rendah yang diasuh/dikelola oleh Al Ittihadiyah. Madrasah-madrasah ini pada mulanya merupakan madrasah yang ada dan dibina oleh para tokoh agama di beberapa daerah. Berkenaan dengan kurikulum yang dipakai pada madrasah-madrasah tersebut, Syahbuddin KS menjelaskan bahwa sebelum bergabung dengan Al Ittihadiyah, mereka memakai kurikulum yang beraneka ragam sesuai dengan 
kehendak para pendirinya, akan tetapi secara umum madrasahmadrasah tersebut hanya mengajarkan mata pelajaran agama. Untuk Madrasah Ibtidaiyah yang diasuhnya, bapak Syahbuddin KS menjelaskan bahwa pada tahun 1941 para siswa diberi pelajaran umum seperti Menulis Latin (bahasa Indonseia), Berhitung, Ilmu Bumi dan Ilmu Hayat. ${ }^{13}$ Setelah mereka bergabung dengan Al Ittihadiyah tidak serta merta dilakukan penggabungan kurikulum yang sama pada setiap madrasah, meskipun usaha ini terus dilakukan oleh Al Ittihadiyah, ternyata baru pada tahun 1957 berhasil dirumuskan kurikulum madrasah yang diberlakukan secara sama di seluruh madrasah yang ada di bawah asuhan $\mathrm{Al}$ Ittihadiyah maupun madrasah yang menyatakan diri bergabung dengan Al Ittihadiyah. Pada tahun 1957 kurikulum yang dirumuskan ini hanya untuk tingkat Tadjhizi, Ibtidaiyah dan Tsanawiyah, karena pada waktu itu Al Ittihadiyah belum memiliki Madrasah Aliyah, yang ada adalah PGA Pertama dan PGA Atas dan kurikulumnya mengikut/diserupakan dengan rencana pelajaran pada PGA Pertama/ Atas Negeri yang diatur oleh Kementerian Agama Republik Indonesia.

Berkenaan dengan masa berlakunya kurikulum pendidikan di madrasah Al Ittihadiyah, bapak Anwar Halomoan Siregar selaku tokoh yang menjabat Sekretaris II PB Al Ittihadiyah hasil Muktamar ke-XI, ketika diwawancarai menjelaskan bahwa kurikulum Madrasah Al Ittihadiyah yang ditetapkan pada tahun 1957 terus dipakai di seluruh madrasah Al Ittihadiyah sampai ditetapkan dan diberlakukannya SKB Tiga Menteri pada tahun $1975,{ }^{14}$ di mana seluruh madrasah yang bermaksud mengikutkan murid-muridnya pada ujian nasional dan memperoleh ijazah negeri, maka wajib mengikuti kurikulum madrasah-madrasah negeri yang diatur dan ditetapkan oleh Menteri Agama Republik Indonesia.

Adapun untuk kurikulum Madrasah Menengah Atas (Qismul 'Ali) yang baru dibuka pada tahun $1959,{ }^{15}$ untuk kepentingan 
para alumninya, disepakati bahwa kurikulumnya adalah mengikut kurikulum Madrasah Aliyah Negeri yang ditetapkan oleh Menteri Agama Republik Indonesia, hal ini seperti yang dijelaskan bapak H. A. Husaini Hasibuan selaku sekretaris Umum Al Ittihadiyah Sumatera Utara periode 2005-2010 dan wakil ketua I periode 2000-2005 yang telah aktif di Al Ittihadiyah sejak tahun 1960-an.

Berkenaan dengan kurikulum pendidikan di madrasahmadrasah Al Ittihadiyah, bapak Ali Saat Sakam, sebagai seorang tokoh senior di Al Ittihadiyah mengemukakan bahwa kurikulum yang ditetapkan dan disepakati oleh Al Ittihadiyah pada tahun 1957 sudah cukup baik dan sesuai dengan kebutuhan pendidikan pada masa itu. Menurutnya, meskipun kurikulum tersebut baru disepakati pada tahun 1957, sesungguhnya dalam pelaksanaannya kurikulum itu sudah dipakai oleh madrasah-madrasah Al Ittihadiyah sejak awal pendiriannya. Walau tidak sama tetapi pada umumnya madrasah-madrasah Al Ittihadiyah dan madrasah-madrasah yang bergabung dengan Al Ittihadiyah, sejak tahun 1940-an telah memasukan mata pelajaran umum seperti Berhitung, Bahasa Indonesia/Menulis Huruf Latin, Ilmu Hayat, Ilmu Bumi, dan Bahasa Inggris (untuk madrasah lanjutannya) ke dalam kurikulum pendidikan mereka. Setelah ada kesepakatan tentang kesamaan kurikulum, seluruh madrasah yang tergabung dalam Al Ittihadiyah memakai kurikulum tersebut pada setiap tingkatan madrasah sampai keluarnya SKB Tiga Menteri tentang Kurikulum Pendidikan di madrasah pada tahun 1975. Ia menjelaskan, bahwa setelah berlakunya SKB tiga Menteri, untuk kepentingan mengikuti ujian Nasional, dipakailah kurikulum Madrasah yang dikeluarkan Departemen Agama Republik Indonesia, untuk seluruh tingkatan madrasah Al Ittihadiyah, kecuali pada tingkat Taman Kanakkanak dan madrasah Diniyah. ${ }^{16}$

Sementara itu, Nurhayati Zein, pengurus bidang pendidikan DPW Al Ittihaidyah Sumatera Utara periode 1999-2005 dan 
Ketua Muslimat Al Ittihadiyah Sumatera Utara periode 20052010 saat diwawancarai tentang kurikulum pendidikan di madrasahmadrasah Al Ittihadiyah menjelaskan bahwa bahwa kurikulum pendidikan yang ditetapkan oleh Al Ittihadiyah pada tahun 1957 sudah bagus dan representatif bagi pelaksanaan pendidikan Islam pada masa itu. Berkenaan dengan pemberlakuan kurikulum tersebut, ia menyebutkan bahwa berdasarkan pengetahuannya kurikulum tersebut telah digunakan di madrasah-madrasah $\mathrm{Al}$ Ittihadiyah sejak tahun 1940-an, meskipun ada sedikit perbedaan pada beberapa madrasah, terutama madrasah-madrasah yang baru menggabungkan diri dengan Al Ittihadiyah. Setelah adanya ketetapan Al Ittihadiyah tentang keseragaman kurikulum pada tahun 1957, seluruh madrasah Al Ittihadiyah memakai kurikulum tersebut dalam kegiatan pembelajarannya, sampai pada tahun 1975 yaitu tahun diberlakukannya SKB Tiga Menteri tentang Kurikulum madrasah di Indonesia. Demikian pula yang dipakai pada madrasah Tsanawiyah dan Ibtidaiyah yang dikelolanya mulai berdirinya tahun 1965 sampai tahun 1975 mengikuti ketetapan kurikulum Al Ittihadiyah tahun $1957 .{ }^{17}$

\section{Metode Pendidikan di Lembaga Pendidikan Al Ittihadiyah}

Seperti diketahui bahwa organisasi Al Ittihadiyah didirikan pada tahun 1935, dan pada masa ini merupakan periode pembaharuan pendidikan Islam, dengan demikian maka lembaga-lembaga pendidikan yang diasuh/dikelola Al Ittihadiyah secara otomatis langsung berhubungan dengan periode pembaharuan tersebut. Artinya, secara formal madrasah-madrasah Al Ittihadiyah telah menyerap ide-ide pembaruan di bidang pendidikan Islam, baik itu yang berkaitan dengan kurikulum, metode ataupun sistem klasikalnya. Tidak jauh berbeda dengan madrasah-madrasah yang muncul pada periode pembaruan ini, madrasah Al Ittihadiyah juga muncul dengan menggunakan sistem klasikal dan metode 
pembelajaran yang bervariasi sebagaimana lazimnya digunakan pada madrasah yang klasikal. Metode tidak puas hanya dengan metode tradisional pesantren, tetapi diperlukan metode-metode baru yang lebih merangsang untuk berpikir ${ }^{18}$ dan meningkatkan keterampilan peserta didik dalam melaksanakan apa yang dikehendaki oleh materi pembelajaran.

Adapun metode pembelajaran yang digunakan pada beberapa madrasah tingkat rendah yang diasuh Al Ittihadiyah terfokus pada metode hapalan, metode demonstrasi, metode latihan, dan menceritakan kisah-kisah Rasul Allah. Hal ini cukup beralasan karena mata pelajaran yang diberikan pada madrasah tingkat rendah merupakan mata pelajaran yang menuntut digunakannya metode pembelajaran seperti ini, di samping juga digunakan metode ceramah. Penggunaan metode ini terus berkembang dan mengalami perubahan mengikut perkembangan kurikulum dan kebutuhan pembelajaran yang terjadi di lingkungan madrasah Al Ittihadiyah. Begitu juga metode pembelajaran pada madrasahmadrasah menengah di lingkungan Al Ittihadiyah yang mulai bermunculan pada tahun 1940-an, karena sudah menerapkan sistem klasikal, metodenya disesuaikan dengan pembelajaran klasikal dan juga dengan kurikulum atau materi pelajaran yang diberikan kepada para peserta didik.

Berkenaan dengan metode pendidikan yang diterapkan pada madrasah-madrasah Al Ittihadiyah antara tahun 1935-1975, beberapa tokoh dan guru pada madrasah Al Ittihadiyah mengemukakan sebagai berikut. Sabullah Siregar misalnya mengemukakan bahwa madrasah tempatnya mengajar telah menggunakan metode pembelajaran modern dan tidak jauh berbeda dengan metode pembelajaran yang diterapkan di madrasah-madrasah Al Ittihadiyah pada masa sekarang ini. Dalam praktiknya, beberapa metode pembelajaran yang pernah diterapkan antara lain adalah metode ceramah, metode tanya jawab, metode diskusi, metode latihan, dan metode 
demonstrasi. Penggunaan metode ini, menurutnya, dilaksanakan secara bervariasi sesuai dengan kebutuhan materi pelajaran yang disampaikan dan tujuan pembelajaran yang hendak dicapai. ${ }^{9}$

Bapak Syahbuddin KS, tokoh dan guru di Madrasah Al Ittihadiyah ketika ditanya berkenaan dengan metode pendidikan yang diterapkan di madrasah $\mathrm{Al}$ Ittihadiyah tempatnya mengajar, menyebutkan bahwa secara umum madrasah-madrasah Al Ittihadiyah tempatnya mengajar sejak tahun 1941 telah menvariasikan beberapa metode pendidikan modern dalam kegiatan pembelajarannya. Ia sendiri dalam melaksanakan tugasnya sebagai guru bidang studi Fikih Ibadah menerapkan beberapa metode pembelajaran seperti metode ceramah, metode tanya jawab, metode demonstrasi, dan metode latihan. Metode ceramah digunakannya untuk menjelaskan beberapa materi yang berkaitan pokok bahasan pelajaran fikih ibadah. Untuk menghindari perbedaan pendapat dan kesulitan siswa menerima materi pelajaran, ia memvariasikannya dengan penerapan metode tanya jawab, dengan tujuan agar peserta didik dapat mengemukakan persoalan yang menjadi pertanyaan pada dirinya dan guru memberi penjelasan. Metode demonstrasi untuk memperlihatkan kepada siswa beberapa kaifiyat atau cara melaksanakan ibadah, seperti berwuduk dan mengerjakan salat, kemudian divariasikan dengan metode latihan dengan maksud melatih siswa melaksanakan/mengerjakan ibadah salat dan berwuduk dengan baik dan benar. ${ }^{20}$

Tidak jauh berbeda dengan kedua tokoh di atas, Nurhayati Siregar selaku pengelola dan guru di Madrasah Al Ittihadiyah di jalan Bromo Medan ketika ditanya tentang metode pendidikan di madrasah Al Ittihadiyah, ia mengemukakan bahwa madrasah yang diasuhnya sejak berdirinya pada tahun 1943 (waktu itu ayahnya sebagai pelopor pendiriannya), telah menerapkan metode pendidikan modern dan tidak sempat menggunakan metode pendidikan klasik, seperti sorogan dan wetonan. Dalam praktik 
pembelajaran di madrasah-madrasah yang diasuhnya beberapa metode pembelajaran yang diterapkan antara lain adalah metode ceramah, metode tanya jawab, metode diskusi, metode resitasi/ pemberian tugas, metode demonstrasi/eksperimen, metode drill/ latihan dan metode bekerja kelompok. Metode-metode ini diterapkan secara bervariasi sesuai dengan materi pelajaran dan tujuan pembelajaran yang hendak dicapai. ${ }^{21}$

Sementara itu, Nurhayati Zein, tokoh Al Ittihadiyah yang menjabat sebagai pembantu bidang Pendidikan DPW Al Ittihadiyah Sumatera Utara dan Ketua Muslimat Al Ittihadiyah Sumatera Utara periode 2005-2010. Berkenaan dengan metode pembelajaran yang diterapkan pada madrasah-madrasah Al Ittihadiyah, ia menjelaskan bahwa metode yang diterapkan telah bervariasi sesuai dengan kebutuhan pembelajaran sistem klasikal dan tidak lagi sempat menyaksikan madrasah-madrasah Al Ittihadiyah menggunakan metode sorogan dan wetonan. Sedangkan metode hapalan dan muzakarah masih tetap digunakan divariasikan dengan metode pendidikan modern yang diterapkan pada lembaga pendidikan sistem klasikal. Hal ini sebagai pengalamannya ketika menjadi siswa pada madrasah Tsanawiyah Al Ittihadiyah pada tahun 1947, guru-guru yang mengajarnya telah menerapkan metode penugasan, diskusi, tanya jawab, latihan, dan demonstrasi. Sebagai seorang guru pelajaran agama Islam yang aktif mengajar di Madrasah Al Ittihadiyah sejak tahun 1965, dalam kegiatan mengajarnya ia telah memvariasikan penggunaan metode ceramah, diskusi, tanya jawab, demonstrasi, penugasan, hapalan, dan metode latihan. ${ }^{22}$

Dengan demikian dapat disebutkan bahwa madrasah-madrasah yang ada di lingkungan Al Ittihadiyah sejak awal pembangunannya telah menggunakan metode pendidikan yang bervariasi dan tidak terfokus pada penggunaan metode sorogan, wetonan, hapalan dan muzakarah yang merupakan metode pendidikan 
Islam pada masa sebelum munculnya ide pembaruan pendidikan Islam di Indonesia. Hal ini terjadi di antaranya karena adanya pengaruh sistem pendidikan Barat yang dibawa ke Indonesia oleh Belanda dan juga faktor pembaruan pendidikan sistem klasikal yang menuntut adanya penyesuaian metode pembelajaran dengan kebutuhan anak didik dan pencapaian tujuan pembelajaran yang hendak dicapai.

\section{Peran Al Ittihadiyah dalam Pembaruan Pendidikan}

Tidak jauh berbeda dari Al Jam'iyatul Washliyah, Al Ittihadiyah juga merupakan organisasi keagamaan Islam yang didirikan pada masa yang bersamaan dengan zaman modernisasi madrasahmadrasah (pembaruan madrasah-madrsah) di Indonesia yaitu suatu masa di mana dimulainya memasukkan pengetahuan umum dalam rencana pembelajaran di madrasah-madrasah, dan hal ini terjadi mulai pada tahun 1931 dipelopori oleh madrasah $\mathrm{Al}$ Jami'ah Islamiyah di Sungayang Batusangkar sebuah madrasah yang dipimpin oleh Mahmud Yunus yang berdiri pada 20 Maret 1931. Setelah tahun 1931, pembaruan kurikulum madrasah terus menyebar ke berbagai madrasah yang ada di Indonesia, meskipun rencana pengajaran madrasah-madrasah itu tidak sama, ada yang memasukkan 30\% pengetahuan umum, ada yang $40 \%$ dan ada pula yang $50 \%$ atau lebih. ${ }^{23}$

Di Sumatera Timur sendiri pada tahun 1931 telah berdiri beberapa madrasah antaranya Madrasah Maslurah berdiri pada 1 Desember 1912, Madrasah Aziziyah didirikan pada tahun 1923, dan Maktab Islamiyah Tapanuli Medan 1918. Madrasahmadrasah ini secara umum pada awal berdirinya hanya memberikan mata pelajaran ilmu-ilmu agama dan bahasa Arab. Namun setelah berkembang ide pembaruan kurikulum madrasah, madrasahmadrasah ini juga tidak ketinggalan untuk memasukan pelajaran 
umum dalam rencana pembelajarannya meskipun dengan persentase yang berbeda-beda.

Dalam kondisi alam pembaruan pendidikan Islam ini, $\mathrm{Al}$ Ittihadiyah lahir dengan membawa serta beberapa madrasah terutama yang dibangun oleh para tokoh yang ikut serta dalam mendirikan Al Ittihadiyah. Sama halnya dengan madrasah-madrasah lainnya yang ada di Sumatera Timur khususnya, madrasah-madrasah Al Ittihadiyah maupun yang menggabungkan diri dengannya juga ikut terimbas dengan ide-ide pembaruan madrasah yang sedang bergulir pada masa itu, terutama yang berkaitan dengan sistem klasikal, kurikulum dan metode pembelajarannya. Terbukti seluruh madrasah yang dibawah naungan $\mathrm{Al}$ Ittihadiyah ataupun yang tergabung di dalamnya, pada tahun 1940 sudah menerapkan sistem klasikal dan sudah mempelajari beberapa pengetahuan umum, seperti Berhitung, Ilmu Bumi dan Menulis Huruf Latin. Hal ini seperti dijelaskan oleh bapak Nuruddin Rangkuti bahwa pada tahun 1940 ia tercatat sebagai murid di Madrasah Ibtidaiyah Al Daoedijah di jalan Antara Medan, yang pada waktu itu baru bergabung dengan Al Ittihadiyah. Penjelasan serupa juga disampaikan oleh bapak M. Suli seorang guru agama yang pada tahun 1940 terdaftar sebagai murid Madrasah Diniyah Haladiniyah di Glugur Medan, yang juga baru bergabung dengan Al Ittihadiyah.

Dalam hal penggunaan metode pembelajaran, Al Ittihadiyah juga terimbas dengan ide-ide pembaruan metode pendidikan yang muncul pada masa itu. Karenanya madrasah-madrasah diniyah dan Ibtidaiyah Al Ittihadiyah sejak awal pendiriannya pada tahun 1936-an sudah menerapkan sistem klasikal dengan metode pembelajaran yang disesuaikan dengan pembelajaran secara klasikal. Artinya murid sebagai peserta didik, tidak lagi duduk bersila secara berhalaqah mengelilingi guru yang memberi pelajaran, tetapi sudah duduk dibangku dan menggunakan papan tulis meskipun sederhana. Dalam proses pembelajaran murid 
duduk secara berbaris ke belakang menghadap ke depan sebagai tempat diletakkannya meja guru dan papan tulis. Adapun metode pembelajarannya, secara umum guru memulai/membuka pelajaran dengan membaca al-Fâtihhah dan doa bersama-sama murid, kemudian dilanjutkan penyampaian materi pelajaran dengan cara ceramah, divariasikan dengan beberapa metode yang sesuai dengan materi pelajaran yang dibahas. Sebelum mengakhiri pelajaran biasanya guru bertanya kepada beberapa murid tentang materi yang telah disampaikan, setelah dijawab oleh murid, barulah guru menutup pelajaran dengan doa bersama murid. Demikian yang diperoleh keterangan dari penjelasan bapak Halomoan Siregar dan bapak Ali Sa'at Sakam selaku tokoh dan aktivis Al Ittihadiyah yang sudah cukup senior dan pada tahun 1940-an terlibat langsung (sebagai murid) dalam kegiatan pembelajaran di madrasah $\mathrm{Al}$ Ittihadiyah.

\section{Penutup}

Dengan menganalisa kondisi pembelajaran yang terjadi di madrasah-madrasah Al Ittihadiyah sebagaimana diuraikan di atas, baik dari segi kurikulum maupun metode pembelajarannya, dapat dipahami bahwa Al Ittihadiyah memiliki peran dalam proses pembaruan pendidikan Islam. Paling tidak, ada dua kesimpulan yang bisa diajukan. Pertama, dalam hal kurikulum pendidikan, pembaruan yang dilakukan Al Ittihadiyah adalah tidak lagi memfokuskan materi pelajaran semata-mata pada materi pelajaran agama dengan titik tumpu pada kitab-kitab klasik dan memasukkan mata pelajaran umum pada kurikulum yang diberlakukan pada madrasah-madrasah Al Ittihadiyah. Adapun mata pelajaran yang mereka masukkan dalam kurikulum pendidikan Al Ittihadiyah adalah Berhitung, Bahasa Indonesia, Ilmu Bumi, Ilmu Hayat, Sejarah, Ilmu Alam, dan Bahasa Inggris. Kedua, pembaruan yang dilakukan Al Ittihadiyah dalam aspek metode pembelajaran 
adalah bahwa para guru di madrasah Al Ittihadiyah tidak lagi semata-mata berpedoman kepada metode sorogan, wetonan, dan hapalan, tetapi telah memvariasikan penggunaan beberapa metode pembelajaran yang sesuai dengan tuntutan sistem klasikal seperti metode ceramah, metode diskusi, metode tanya jawab, metode demonstrasi, metode hapalan, dan metode latihan/drill.

\section{Pustaka Acuan}

Al Rasyidin. "Organisasi Islam di Tanah Melayu: Ideologi dan Gerakan Al-Ittihadiyah Sebelum Era Reformasi," dalam Journal of Contemporary Islam and Muslim Societies, Vol. 2, No. 1, 2018.

Azra, Azyumardi, et al., Ensiklopedi Islam, Jilid II. Jakarta: Ichtiar van Hoeve, 1999.

Azra, Azyumardi. "Muhammadiyah: A Preliminary Study," dalam Studia Islamika, Vol. 1, No. 2, 1994.

Azhar, Bachroem, et al. Peringatan Ulang Tahun 1/4 Abad AlIttihadiyah. Medan: Panitia Kongres ke-X Al-Ittihadiyah, 1960.

Bakar, Mahmud Abu. "Muktamar ke-XII Al-Ittihadiyah," dalam Muchlis Arsjad et al. Buku Muktamar Al-Ittihadiyah ke XII. Bandung: Seksi Publikasi Panitia Muktamar, 1968.

C.V.O Conferentie Al-Ittihadiyah. "Azas, Toejoean, Oesaha, dan Organisatie Al-Ittihadiyah," dalam Conferentie Jubileum 6 Tahoen 1935-1941 Al-Ittihadiyah. t.t.p.: C.V.O. Conferentie Al-Ittihadiyah ke-1, 1941.

Daulay, Haidar Putra. Sejarah Pertumbuhan dan Pembaruan Pendidikan Islam di Indonesia. Bandung: Citapustaka Media, 2001.

Ja'far. AlJam'iyatul Washliyah: Cita-cita Keislaman dan Keindonesiaan. Banda Aceh: PeNA, 2018. 
Munhanif, Ali. "The Khittah of 1926 Reexamined: Views of the NU in Post-Cipasung Congress," dalam Studia Islamika, Vol. 3, No. 2, 1996.

Nazir, Moh. Metode Penelitian. Jakarta: Ghalia Indonesia, 1988.

Saragih, Aliman. "Kontribusi Al Jam'iyatul Washliyah terhadap Kemerdekaan Indonesia (1930-1950),” dalam MIQOT: Jurnal Ilmu-ilmu Keislaman, Vol. 40, No. 1, 2016.

Siddik, Dja'far dan Rosnita. "Gerakan Pendidikan Al Washliyah di Sumatera Utara," dalam Ulumuna: Journal of Islamic Studies, Vol. 18, No. 1, 2014;

Steenbrink, Karel A. Pesantren Madrasah Sekolah Pendidikan Islam dalam KurunModeren. Jakarta: LP3ES, 1991.

Suharto, Toto. "Ma'had Ittihad al-Islam (Persis) 1984-1996 wa alTa'lim al-Qa'im 'ala Da'amah al-Mujtama',' dalam Studia Islamika, 11, No. 1, 2004.

Thaib, M. Hasballah. Universitas Al Washliyah Medan Lembaga Pengkaderan Ulama di Sumatera Utara. Medan: Universitas Al Washliyah, 1993.

Yunus, Mahmud. Sejarah Pendidikan Islam di Indonesia. Jakarta: Mutiara Sumber Widya, 1992.

Wawancara dengan Ali Saat Sakam, Tokoh Al Ittihadiyah, di Medan, 23 Mei 2005.

Wawancara dengan Anwar Halomoan Siregar, Tokoh Al Ittihadiyah, di Medan, 22 Januari 2005.

Wawancara dengan Nurhayati Siregar, Guru Al Ittihadiyah, di Medan, 8 Agustus 2005.

Wawancara dengan Nurhayati Zein, Tokoh Al Ittihadiyah, di Medan, 12 Maret 2005.

Wawancara dengan Sabullah Siregar, Guru dan Tokoh Al Ittihadiyah, di Medan, 19 Pebruari 2005.

Wawancara dengan Syahbuddin KS., Tokoh Al Ittihadiyah, di Medan, 10 Januari 2005. 


\section{Catatan Akhir:}

${ }^{1}$ Ali Munhanif, "The Khittah of 1926 Reexamined: Views of the NU in PostCipasung Congress,” dalam Studia Islamika, Vol. 3, No. 2, 1996.

${ }^{2}$ Karel A. Steenbrink, Pesantren Madrasah Sekolah Pendidikan Islam dalam KurunModeren, (Jakarta: LP3ES, 1991), h. 61.

${ }^{3}$ Toto Suharto, "Ma'had Ittihad al-Islam (Persis) 1984-1996 wa al-Ta'lim alQa'im 'ala Da'amah al-Mujtama'," dalam Studia Islamika, 11, No. 1, 2004.

${ }^{4}$ Azyumardi Azra, "Muhammadiyah: A Preliminary Study," dalam Studia Islamika, Vol. 1, No. 2, 1994.

${ }^{5}$ Peran Al Washliyah dalam bidang pendidikan dapat dibaca dalam Dja'far Siddik dan Rosnita, "Gerakan Pendidikan Al Washliyah di Sumatera Utara," dalam Ulumuna: Journal of Islamic Studies, Vol. 18, No. 1, 2014; Ja’far, Al Jam’iyatul Washliyah: Cita-cita Keislaman dan Keindonesiaan (Banda Aceh: PeNA, 2018). Peran organisasi Al Washliyah dalam bidang politik, lihat ulasan artikel Aliman Saragih, "Kontribusi Al Jam'iyatul Washliyah terhadap Kemerdekaan Indonesia (1930-1950)," dalam MIQOT: Jurnal Ilmu-ilmu Keislaman, Vol. 40, No. 1, 2016.

${ }^{6}$ Baru-baru ini diterbitkan artikel karya Al Rasyidin, "Organisasi Islam di Tanah Melayu: Ideologi dan Gerakan Al-Ittihadiyah Sebelum Era Reformasi," dalam Journal of Contemporary Islam and Muslim Societies, Vol. 2, No. 2, 2018.

${ }^{7}$ Moh. Nazir, Metode Penelitian (Jakarta: Ghalia Indonesia, 1988), h. 66.

${ }^{8} \mathrm{M}$. Hasballah Thaib, Universitas Al Washliyah Medan Lembaga Pengkaderan Ulama di Sumatera Utara (Medan: Universitas Al Washliyah, 1993), h. 199.

${ }^{9}$ Bakar, Mahmud Abu. "Muktamar ke-XII Al-Ittihadiyah," dalam Muchlis Arsjad et al. Buku Muktamar Al-Ittihadiyah ke XII. Bandung: Seksi Publikasi Panitia Muktamar, 1968, h. 18. h. 287.

${ }^{10}$ Azyumardi Azra, et al., Ensiklopedi Islam, Jilid II (Jakarta: Ichtiar van Hoeve,1999),

${ }^{11}$ Mahmud Abu. "Muktamar ke-XII Al-Ittihadiyah," h. 19.

${ }^{12}$ Azra, et al., Ensiklopedi Islam, h. 288.

${ }^{13}$ Wawancara dengan Syahbuddin KS., Tokoh Al Ittihadiyah, di Medan, 10 Januari 2005.

${ }^{14}$ Wawancara dengan Anwar Halomoan Siregar, Tokoh Al Ittihadiyah, di Medan, 22 Januari 2005.

${ }^{15}$ Azhar, Bachroem, et al. Peringatan Ulang Tahun 1/4 Abad Al-Ittihadiyah. (Medan: Panitia Kongres ke-X Al-Ittihadiyah, 1960), h.40

${ }^{16}$ Wawancara dengan Ali Saat Sakam, Tokoh Al Ittihadiyah, di Medan, 23 Mei 2005.

${ }^{17}$ Wawancara dengan Nurhayati Zein, Tokoh Al Ittihadiyah, di Medan, 12 Maret 2005.

${ }^{18}$ Haidar Putra Daulay, Sejarah Pertumbuhan dan Pembaruan Pendidikan Islam di Indonesia (Bandung: Citapustaka Media, 2001), h. 67. 
${ }^{19}$ Wawancara dengan Sabullah Siregar, Guru dan Tokoh Al Ittihadiyah, di Medan, 19 Pebruari 2005.

${ }^{20}$ Wawancara dengan Syahbuddin KS., Tokoh Al Ittihadiyah, di Medan, 10 Januari 2005. 2005.

${ }^{21}$ Wawancara dengan Nurhayati Siregar, Guru Al Ittihadiyah, di Medan, 8 Agustus

${ }^{22}$ Wawancara dengan Nurhayati Zein, Tokoh Al Ittihadiyah, di Medan, 12 Maret 2005.

${ }^{23}$ Mahmud Yunus, Sejarah Pendidikan Islam di Indonesia (Jakarta: Mutiara Sumber Widya, 1992), h. 102. 